\title{
The influence of Chinese folk embroidery of modern fashion design
}

\author{
Yugang Chen ${ }^{1, a}$ \\ ${ }^{1}$ Jiangxi Institute of Fashion Technology, Jiangxi, Nanchang, 330201 \\ a28941204@qq.com
}

Keywords: Folk embroidery; Clothing design; application

\begin{abstract}
Traditional folk embroidery belongs to Chinese intangible cultural heritage, to apply Chinese traditional embroidery of the innovation of the modern garment design, can make up for any deficiencies in the modern fashion design, but also satisfy people pursue personalized, the uniqueness of the demand on the vision. Based on Chinese traditional embroidery technology application in modern fashion design carried on the thorough analysis, so as to promote fashion design with Chinese characteristics to the international big stage.
\end{abstract}

\section{The introduction}

Chinese embroidery is an art, is also a brilliant, it embodies the glory and wisdom of Chinese traditional art, is an important part of the Chinese nation excellent culture heritage. Nowadays, with the development of social economy, the renewal of the knowledge system, the change of the aesthetic idea, makes it the pursuit of modern clothing has a new desire. Apply Chinese traditional embroidery to modern fashion design, we just follow its techniques, but also make full use of modern new material, new technology, new technology, the traditional embroidery closely integrated with modern clothing, innovative design, which fully reflects the modern clothing fashion and personalization, enhance the visual impact of the modern and artistic expression, and meet the demand of people pursuit of beauty in modern dress, let the traditional embroidery to the stage of modern clothing.

\section{Description of folk embroidery}

Will now be embroidery applied to more and more in the clothing, embroidery technology now is more than just apply to customs in celebration, a traditional festival of traditional costumes, and integrated into the modern clothing, was welcomed by many designers. In a lot of high fashion, often use hand embroidery to reflect dress delicate and costly, used in the clothing embroidery craft, choose to have the pattern of auspicious implies can reflect people's best wishes, but also can reflect national religion culture by embroidery, enhance cultural connotation of clothing.

Embroidery is a kind of fabric has been completed on the creation of art, on the fabric with needle repeatedly lead to wear around the patterns of the formation of a kind of decoration. China's vast territory, due to the customs and geographical differences, the embroidery varieties and technology of the differ in thousands ways, and formed a variety of embroidery styles. But from the embroidery embroidery craft method, can be roughly divided into three categories: hand-embroidered, electronic control machine embroidery, sewing machine embroidery. One hand embroidery stitch with a flexible, adornment effect good characteristic, is suitable for all kinds of clothing and fabric on the needlework. In the design of modern clothing, usually applied to he, bead embroidery, hollow embroidery, cutwork embroidery, ribbon embroidery and other craft techniques.

\section{Traditional folk embroidery in the modern clothing innovation design method}

Use design breakthrough thinking innovation. In the clothing embroidery patterns will be the layout of formal beauty reflected is the key of the design. Embroidery embroidery pattern is the most intuitive visual factors. But according to the characteristics of the modern clothing and modern aesthetic point of view, we can also find the traditional embroidery pattern has some limitations in the layout, it is affecting the embroidery in the application of modern clothing. Therefore, we need to embroidery decorative pattern for innovation. The embroidery on the location of decoration in 
the traditional dress is unitary. However, with the improvement of people's living standard, people's aesthetic idea in constant change, the style has changed, the adornment of the fixed position can't satisfy people's demand for clothing. So you need to bold innovation embroidery patterns. Italian brand Marni dress design, can draw lessons from it in the fashion and design decorative parts of the change of traditional Chinese clothing. Embroidery on the skirt waist level on the a colorful belt, the location of the embroidery on the hip is exaggerated to design, it reflected the essence of Chinese traditional clothing art, and it contains the characteristics of the modern western clothing. Therefore, when making the embroidery can try in some special parts for decoration, give a person a visual impact.

Innovative use of new materials in clothing. Glimmer of traditional embroidery technique according to the pattern of embroidery, very slow, can't be on a large scale, into batch production. This makes the embroidery generally appear in the traditional Chinese qipao, European haute couture and haute couture gown, and rarely appears in the lives of ordinary people. Traditional embroidery are used on the fabric color embroidery line, stitch neat but lack of change. In the design of modern clothing, the traditional embroidery technology is obviously not enough. Therefore, add a lot of new materials in modern clothing, no longer simply just use embroider line, but the choice and the material of fabric to match to make use of the transformation and innovation. As in casual clothes, wool embroidery, yarn is the material of modern elements, compared with the traditional embroider line, embroidered the effect of the coarse yarn can quickly, save time and manpower, can be applied in the ordinary consumers. Texture is fluffy and yarn itself, can make a design more fluffy cute when embroidery. Other clothing bead piece on the rope embroidery, fashion embroidery, the embroidery for the modern clothing increased the effect of a different artistic beauty.

Today, embroidery gradually in a new way of physical form and spirit into the modern fashion design and production. Traditional form and content, although rare, already cannot satisfy the requirement of modern development. With the development of high-tech technology, the application of computer design, the unceasing change of embroidery patterns, these to break the traditional embroidery technology time-consuming, less time-consuming, patterns, such as limited. Clothing design concept need to implement processes, change of process innovation often brings to the designer's inspiration. Nowadays, traditional embroidery craft to the modern technology of production in the direction of the shift. As computer embroidery machine, hair machine embroidery and other equipment and technology has been widely applied to the garment industry, embroidery technology has developed from the traditional folk craft to become a highly efficient, delicate, rich variety of high-tech embroidery craft designs. At the same time, because most modern young people in the pursuit of fashion and personalized, they want to show their favorite things, therefore, it has been a kind of personalized show process, can be in a short time will be like the pattern on the clothes, and be the same as the embroidery effect of the finished product.

The application of the new design idea in modern clothing. By using modern scientific and technological achievements of the change of material in the traditional embroidery technology, production process and restriction on concept, constantly developing new embroidery materials and a variety of hybrid application of the material, breaking the traditional embroidery form of surface decoration. Should not be used on some clothing pattern design of traditional embroidery method, but is stereo flowers design, can be used for buttons and other decorative clothing, make classic clothing also has a vivid stereo feeling. Produce flowers can also with sequins, precious stones, beads and other decorations. As in western-style wedding dress is adopted on the ribbon embroidery, ribbon embroidery color is rich, decorative pattern is marked and has strong stereo feeling, make fine gauze texture of flowers on the dress more eye-catching and prominent, enhanced a stereoscopic effect, this wedding dress, give a person a kind of dreamy beauty.

\section{Application of embroidery and embroidery design for the influence of modern clothing}

Meet the aesthetic psychological needs of consumers. Chinese embroidery in the creative design and apply in the modern clothing has gradually to the fashion of the world, and walk more 
and more gorgeous, more and more make public, the time to show people the style of its fashion, nostalgia, bouncy, therefore, it is also more in line with modern consumer aesthetic requirement of embroidery clothing. Now people's life in the fast rhythm, good efficiency of society, people are more inclined to pursue the return of the nature. This idea to the aesthetic idea of people tend to life, natural belongs to traditional folk crafts, embroidery, the application of it can make people feel natural and honest. At the same time also for the modern clothing injected with deep cultural connotation. Designers use their unique creativity and imagination of flexible to apply traditional embroidery elements of modern fashion design, to consumers in general clothing rare visual effect, for the modern clothing gives life, not only the clothing is practical, has the very high aesthetic value at the same time, and that it is better to meet the modern aesthetic psychological needs of consumers.

Opening up new design style. Best costume design requires not only the color, function, with the decoration and so on to unify, at the same time also require clothing to reflect the design values, culture and fashion sense. Chinese folk embroidery as design elements into the design of modern clothing, changed the original clothing design style. Blend in Chinese traditional embroidery culture into the modern fashion design, make the modern clothing has a special artistic beauty. Many foreign designers looking for creative inspiration from Oriental style, to apply Chinese traditional elements of design. Such as DIOR designer John galliano degrees will be used in modern fashion design of Chinese embroidery, in the light of gauze dress with embroidered flowers, let the dress has more romantic fashion sense, perfect blend in Oriental verve in the west wind of fashion design.

To improve the added value of clothing. Hand embroidery due to time consuming, labor costs higher reasons, it cannot be conducted on a large scale production, but the hand embroidery bring clothing personalized and added value of the infinite are other workmanship is irreplaceable, so the hand embroidery for the design of high fashion. In recent years, an upsurge in China in international fashion wind, such as embroidery, prepare the craft as a design element applied to fashion design, and even in some high fashion has spent hundreds of hours of hand embroidery to increase the visual effect of clothing. Some of the world's top designers to apply Chinese embroidery culture of clothing design. In addition, with the Chinese style of Chinese traditional embroidery clothing, with exquisite workmanship, profound meaning, the picture and beautiful embroidery patterns, therefore was welcomed by overseas customers and love.

\section{Conclusion}

Chinese folk embroidery application in modern fashion design, combine Chinese traditional culture and modern fashion design, give full play to the unique charm of Chinese embroidery. This not only can satisfy the need of modern fashion consumption, to create a good economic benefit, but also can carry forward the Chinese national culture, promoting China's clothing fashionable design to the international big stage.

\section{Reference}

[1] Yusheng ZhangYang. Xiaoru zhou. Chinese folk embroidery application in modern product design [J] movie review, 2012 (9) : 45-47.

[2] Guan LiPing. Embroidery elements application in modern fashion design study [J] light textile industry and technology, 2012 (12) : 66-68.

[3] Wei Yulong. Embroidery innovation in modern clothing design and apply the research [D] jiangnan university, 2009 (6). 